\title{
加强重工業方面的科学技術研究工作·
}

\section{刘 涁}

（重工業部）

我國鋼鉄工業、有色金蜀工業、基本化学工業、建筑材料工業, 經过工栄的恢復時 期、進入工業的建設時期之後，随着机械电机工業、國防工業、農栄以及國民絓济各部 阴的迅速發展, 已經面臨了新的情况和新的任务。

这首少是由於重工業部各企業主要是工箖些產上的材料工業部阿, 我們必須为其他 工業部門生產最新式、最先進的各种類型、性能的新暗品提供原材料。如果我們不能供 应品种很多、标準很嚴的黑色与有也金屬材料，甚本化学与建築材料工業的合乎标蕉的 起品, 就不能遌应机械电机工業、近代國防工栄、農業以及國家基本建設發展的需要。 这一特點决定了重工栄部各企業必須迅速發展生產技術，把它們的技術經济指标和品利、 虽量的工作逐少地提高到先進的苏联水本。

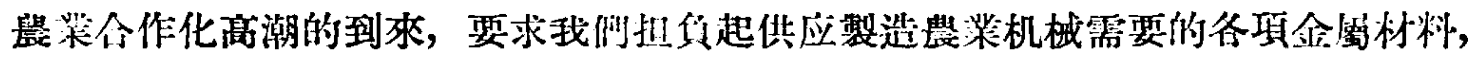

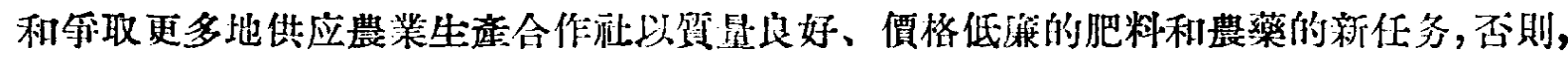

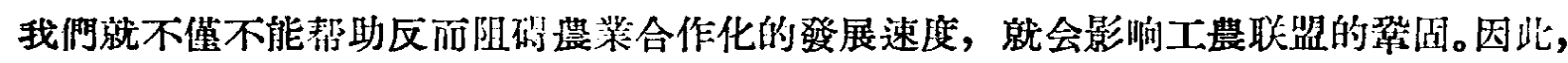
發展生產技術在目前决不僅僅只是一个技石問題或業务問題, 並且也是一个具有重大原 則性的政治問題。

國际科学技術的發展䞨势已經進入新的階段，这也是我們面臨的主要情况。苏联部

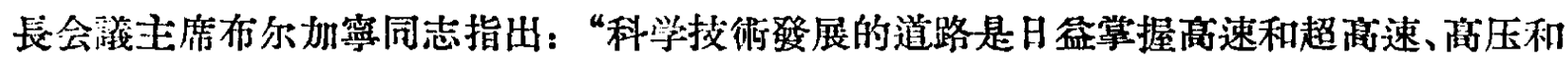

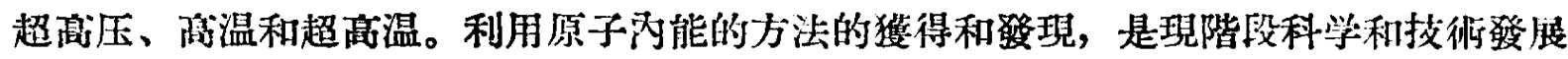

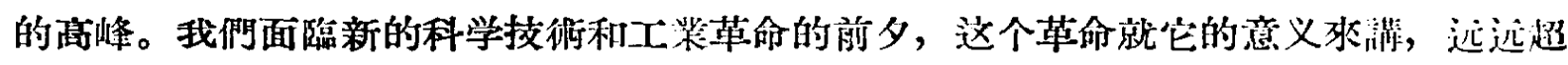

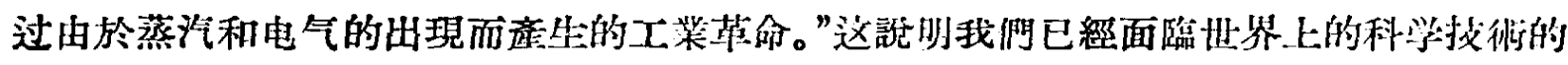

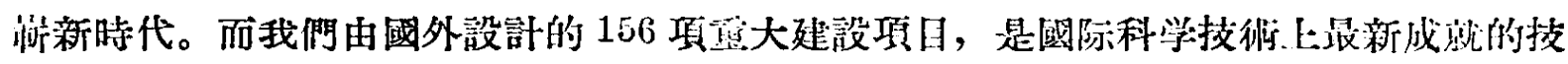

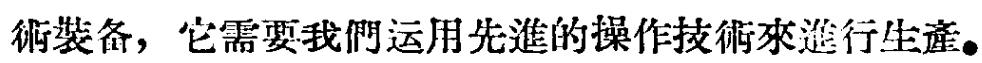

因此，我們的任务就在於深刻認識到这一形势的發展与变化，伐我們的岕想 ${ }^{3}$. 工作適应新的事物的發展；是学驾苏联及其他國家的先進經䮑；在尽可能迅速的条作下

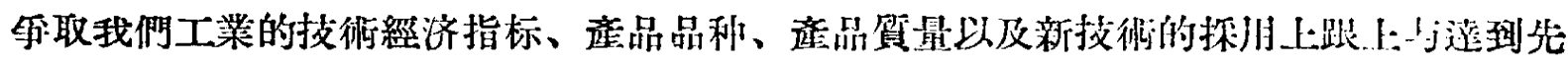

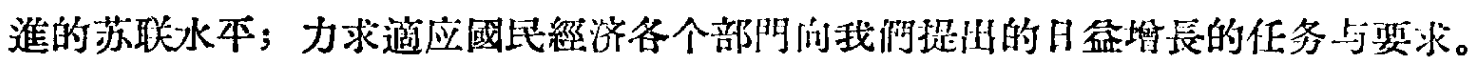

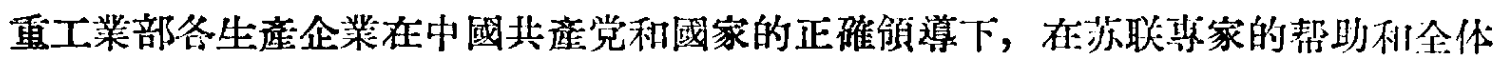

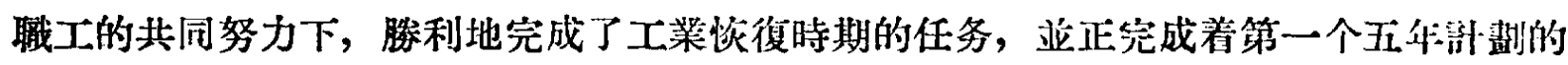

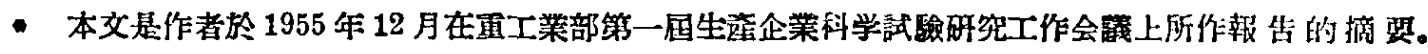
一䊮者。 
建設任务。幾年本光其是近兩年來, 我們在技術發展方面, 特別是在撗大道品品种和改

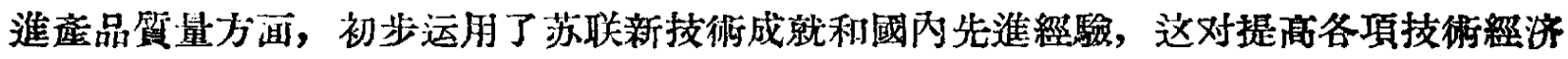
指标和提高企業水本上具有雷要意义。这样就使重工業部全部企業的技術維济指标有了

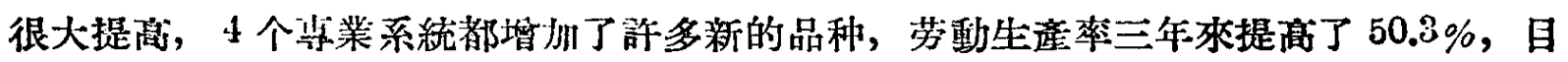

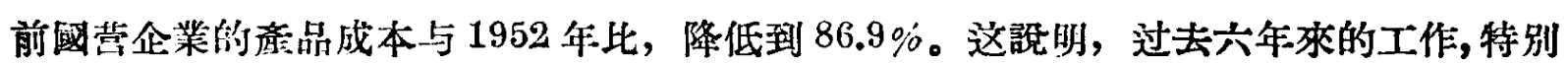

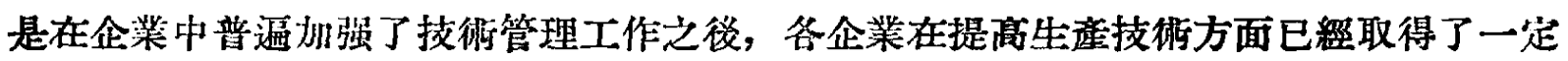
的成精, 而且为今後進一步的發展打下了基礎。

但是, 我們地必須認識到另一方面的重要事实, 这就是我們目前的生库, 無論是在 技術經济指标、品种數量、質量水平以及新技衡的採用上, 都还幼稚年輕, 如果和苏联

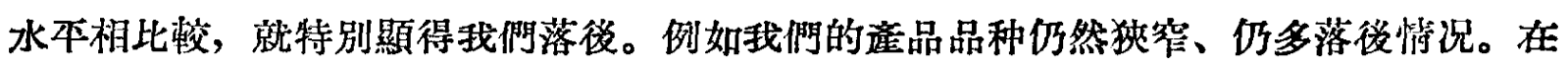
技術經济指标方面与苏联水平比較也是落後的，如磺山回探率苏联一般为 $85 \%$ ，我們最 间䄪为 $70 \%$ 左右，最低的竞在 $50 \%$ 以下; 有色金屬冶煉的金屬損失率高, 如能達到苏 联标淮，每作就能增加大量金屬的回收; 化工原料的消耗定額过滈; 建工水泥籍的本均

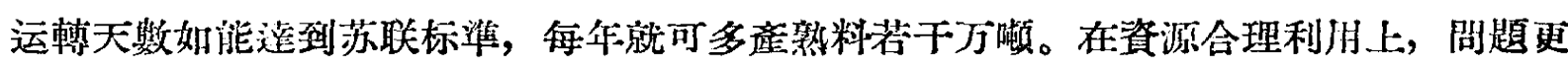

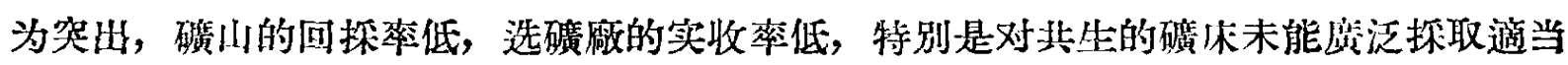
的选棣方法進行有色金屬的綵合利用。所有这些情况，都說明任何由於獲得某些工作上 的成就因而產生自滿与保守情緒都是錯誤的。

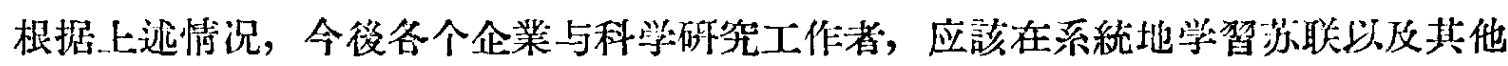

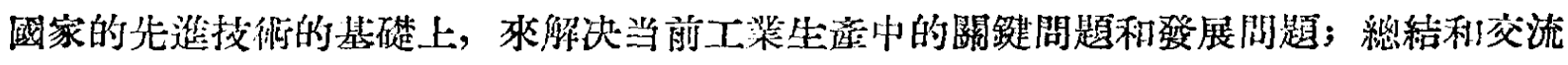

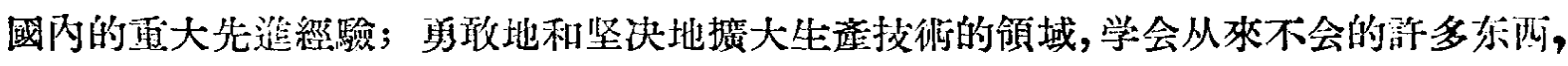

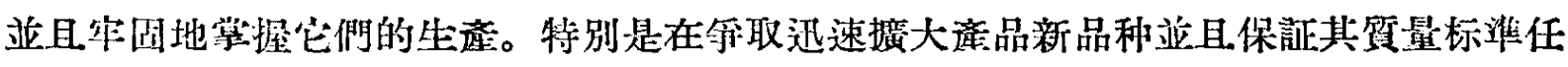
务上, 要求我們系統地探用新的技術成就, 更有系統地廈大品种。为此, 我們就有必要

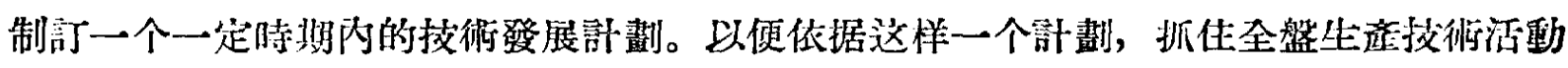

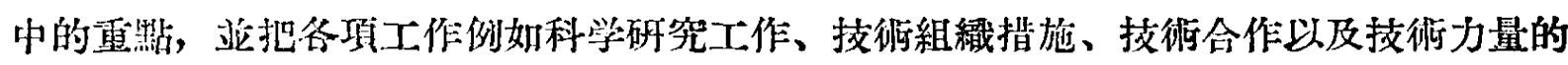
配备等項工作指施，邀当地結合起來。

以下僅就鋼鉄工業、有色金屬工業、化学工業及建筑材料工業在今姼啢年內，挍術 發展摽劃中的若千重點問題加以扼要的說明:

\section{一 鋼鉄工業}

鋼鉄工業今後兩年內应該是加强原料基地及原料淮备工作，有再點地推廣新技術，

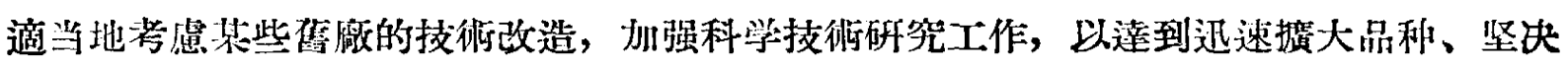
改進質量、提高技術經济指标、降低成本的目的。

为了達到上述總的要求，鋼鉄工業今娞兩年》的技石方針和方向如下:

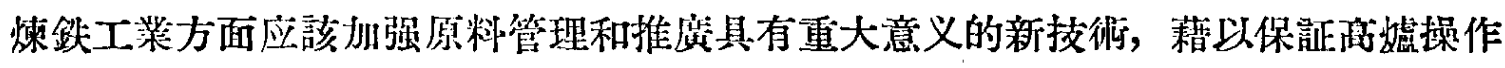

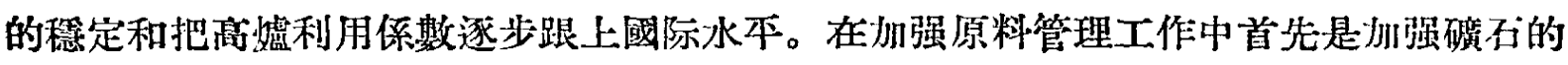
淮备工作。使入蝔磺石成分的波動降低到最小限度; 其次, 利用粉磺或富选精粉製成成 碱度自熔性燒結礦, 改進初渣形成狀态, 提高冾棣强度; 第三, 改淮焦炭虽量, 提诚焦 炭的强度, 降低灰分, 改淮粒度, 減少波動。为了改淮焦炭質量, 必須做好原料的探选
1 月号
科学通報

- 35 • 
混匀工作，系統研究和探用適当的符合中國資源条件的配煤制度，並大力加强調火及熱

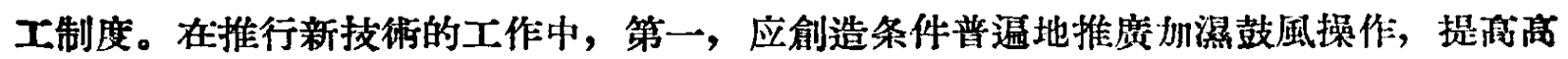

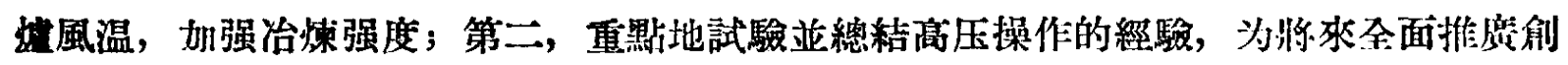

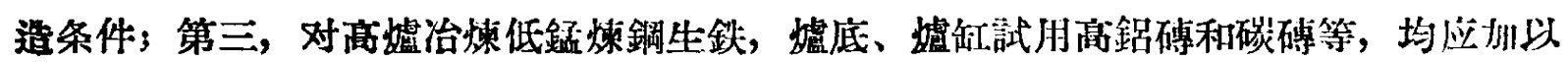
研究与推廣。鑑於高嘘結㨨構成为歷年來梀鉄工業的主要弱點, 因此有必要在 1956 年

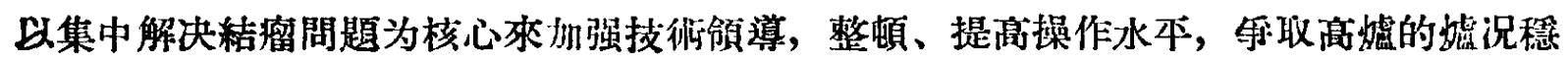
定和順行, 克服不均衡生迹的弱點。

煉鋼工業方面: 今後兩年內在技術發展上应該加强以下雨个方面的工作：第一，推

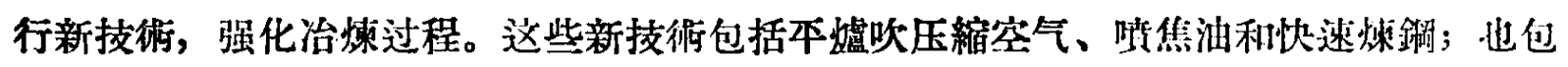

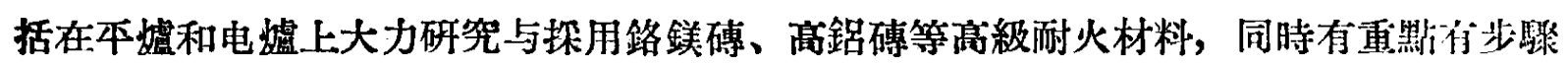

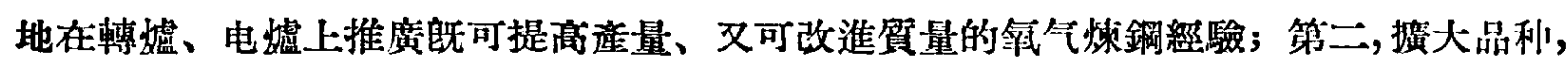

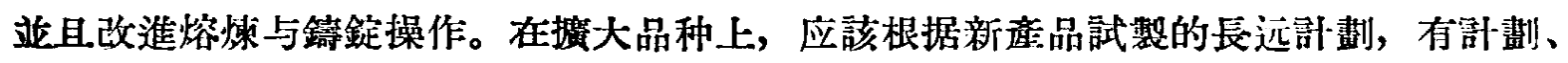
有組䄉地進行。銡錧工作除了应該推席鎮静鋼保温帽电弧吹氯及火焰加熱法，推度喘钟

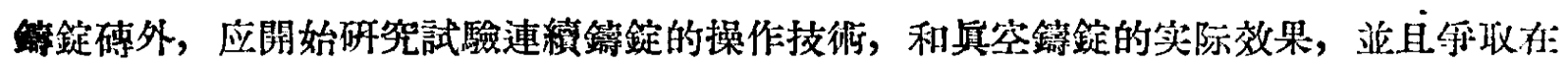
生差現場逐步探取。此外，对現有嘘体的改造及分倣、分嘘哥業分工制度等，也应度证

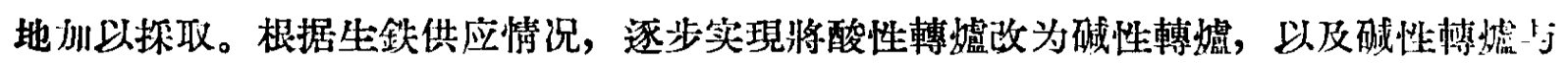
电嘘的双咲操作。

为了有效地提配鋼的生水本並且大力改善其賀量情况, 在 1956 年的技術發展任务 中, 有必要在全國电爐工廠把提高質量、撗大品种列为首要任务, 各項工作应国繶於这

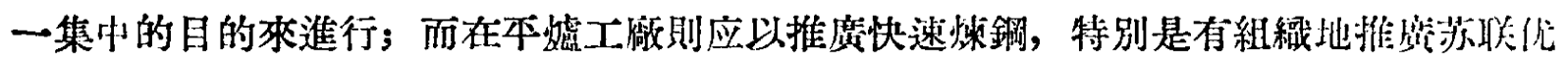
秀煉鋼工柯列斯尼柯夫快速煉鋼的先淮經驗。

鋼鉄加工与熱处理方面: 今後兩年內应做好以下工作：第一，探取必要拈施垘加銅

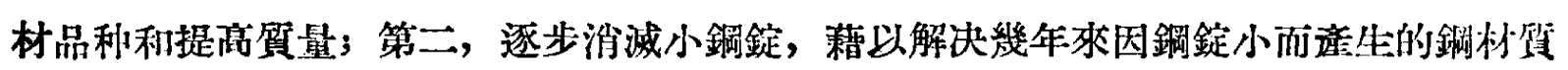

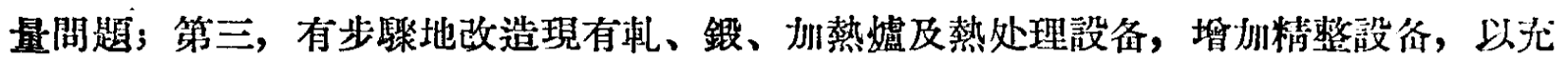

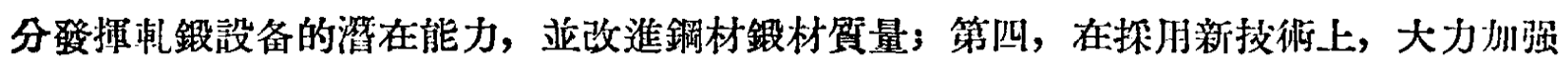

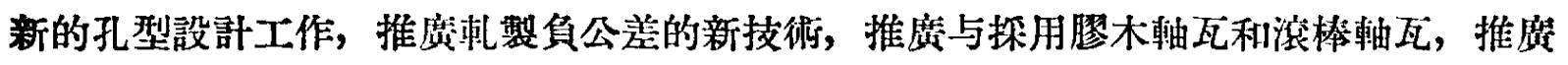
球墨鍄鉄䡉輥，淮一步提高洓輥質量。

耐火材料工業方面: 今後雨年內的主要任务, 首先是合理利用資源, 逐步加强现行各 酎火材料礦區及新磺區的地質勘垛工作; 亚且系統地研究其基本性能, 然後揬地區確定

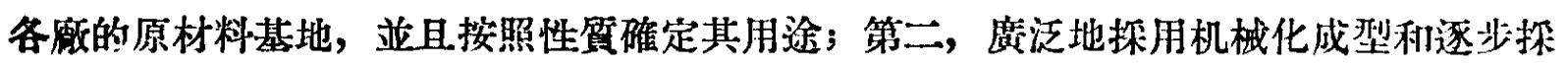
用高压成型問題，孚取兩年內机械成型達到 65一70\%；第三，燳加新道品。目前最重要

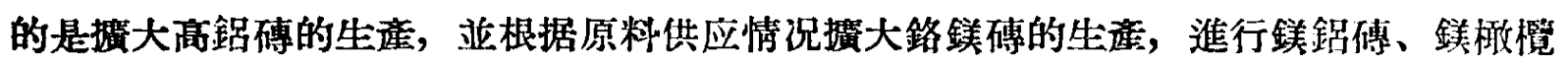
石磚、輕質磚、确矽碳、磚、碳化矽磚的研究試製, 藉以使耐火材料工業的發展能 適应冶煉工業及其他工業部門發展的要求。

\section{二 有色金曘工業}

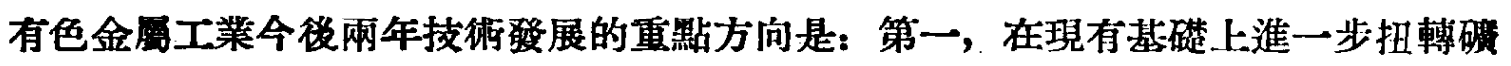

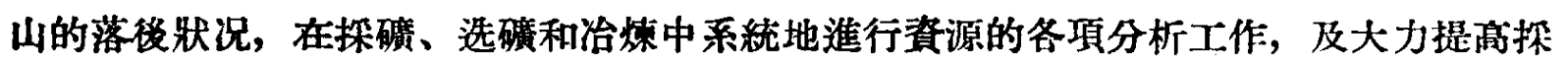




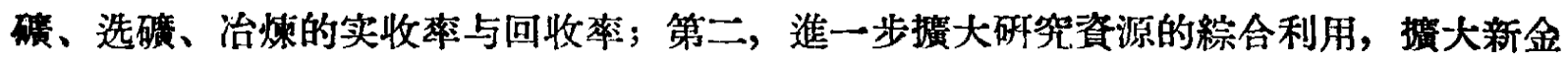

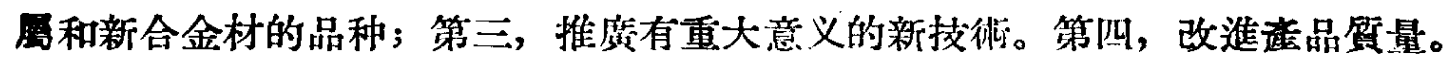

在探磺工作方面; 第一, 以編製和買微技術採掘計劃为中心, 繼續加强地筫測量工. 作，争取雨年內主要磺山的主要礦區經常保有一定數量的開拓磺量和探磺淮备礦量，以 保姃磺儿的正規作業和安全作業; 第二，有步骤地改進探磺方法; 今㷋兩年內应該根据

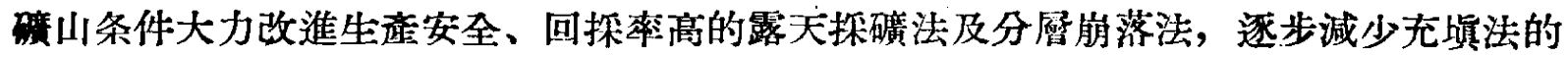

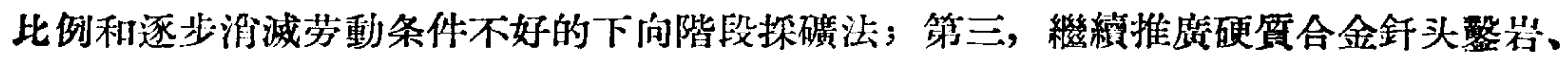
改淮爆孔排列、推行深孔爆破等先淮經驗。

选磺方面：今後兩年內应着重探取下列措施：第一,加强有用磺物的綜合利用工作， 首先是对資源倘末查清的共生的磺体進行取样分析与磺物鑑定，根据有用金屬及希有金 量的含, 研究回收方法; 对資源情况已查清的多金屬共生的黉体, 則迅速組織回收或 研究回收的方法; 第二, 研究和推黃新的选礦方法, 例如重介䫓选磺法, 抬浮选磺法(包

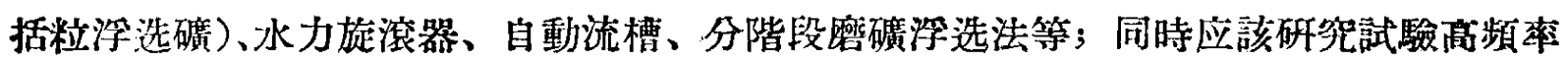
淘然机、濕式选黉法等, 以回收共生礦物, 提泉选磺实收率; 此外, 还应研究处理氧化

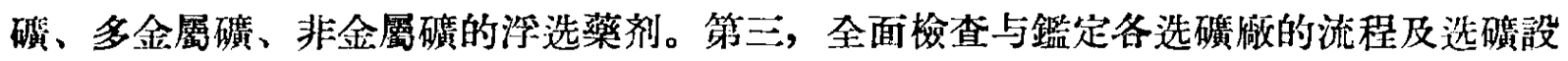
备的使用情况，䒚探取有效措施，以提高选磺能力和回收率。

冶棣方面：加强研究有用金屬的綜合利用，援大金屬品种、改造㙅作技石、提调金

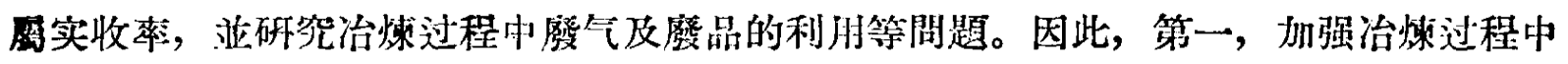
有用金屬的綜合利村, 並且大力加强已試製成功的共生金屬的回收工作; 第二, 結合选

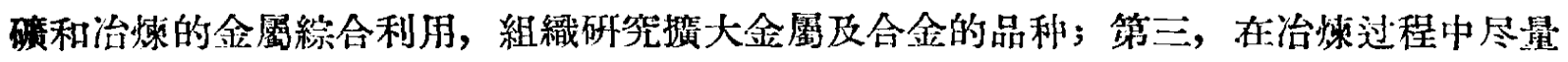
減少治情損失及沿中含金屬量; 对筑品与副道品的回收工作加以研究; 第四, 在推行新

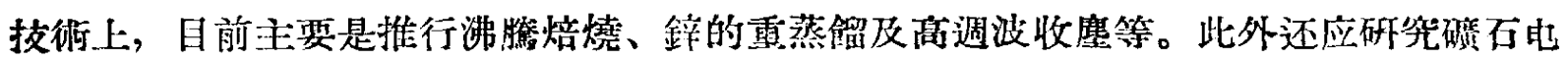

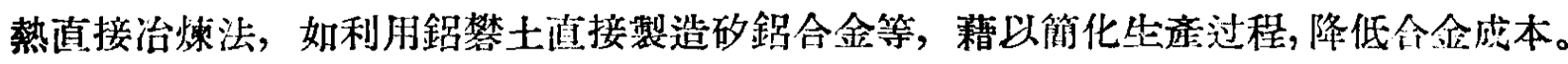

有色金屬加工方面：擴大品种与改淮質量。今後兩年的重點指施是除建設新做外， 应該利用現有設备摭大生迹品种並且解决筫量。

\section{三 化学工業}

化学工業当前最突出的問題是品种狹窄, 質量波動。因此, 今後兩年內化学工業的 技術發展重點問題, 是解决重要迹品的品种問題和質量問題。而对与農業有關的网品（肥

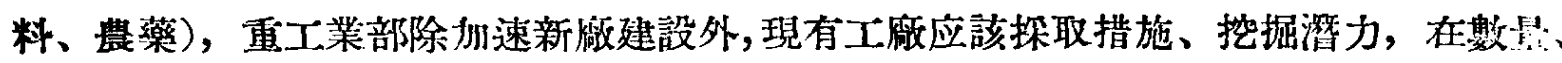
斵量以及成本的降低上做到尽可能多地滿足農業發展的需要。

在肥料生產問題上, 目前肥料庨量远不能滿足農業發展的需要。因此我們除加速新

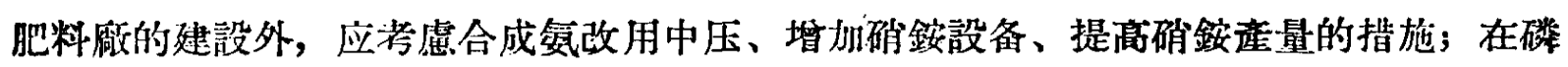
吧方面則应積極勘察資源, 淮行試驗研究及工嫄設計的工作。釬肥方面也应对資源情况 与生交方法進行一系列的研究工作。应根据土壤和農作物的情况, 与農業部門的科学研 究机粠進行關於肥效的綜合研究工作。

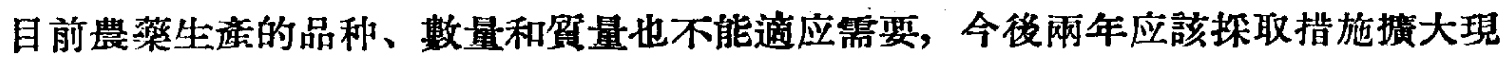
有丧藥的品种和數量, 並且大力提高農藥的䓄量。
1 月号
科学通報 
染料与染料中間体的生梌: “目前然出的問題是品种少。我們需要按照統筹分工的原 則, 研究染料工業調整發展方案, 粒一安排生產。需要探取有效措施, 拱大品种、保証 貿量，争取在 1960 年內完成坦加染料及染料中間体 300 利的任务。

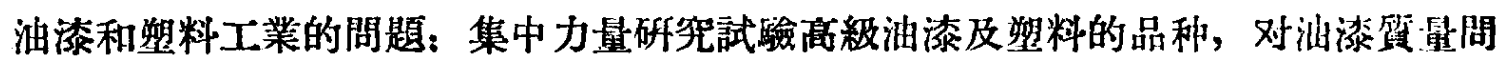
題, 有關企業要在明年切实解决; 結合油涵及塑料發展部劃, 逐步解决迫切需要的有机 合成溶剂及樹脂等問題, 並应在民用生道上加以考虑, 藉以为塑料工業的發展倒造有利 条件。

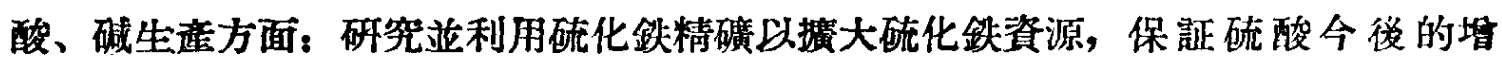

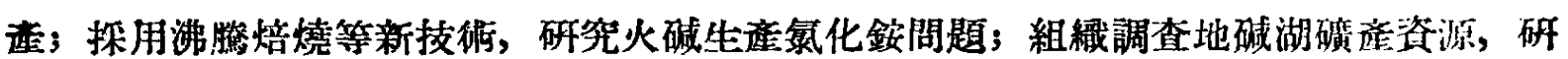
究提出天然碱、鉀監及矹酸等差品的生座問題。

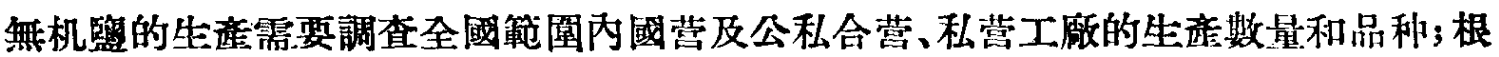

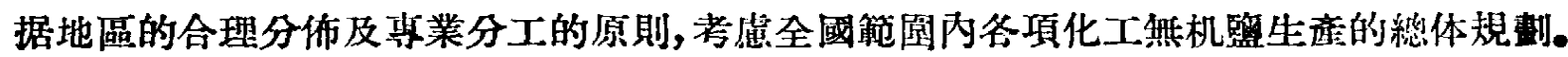

另外, 还应組峨力量, 系統地研究煉焦工業化学道品的回收与進一步加工利朋的規 劃間題。

\section{四 建築材料工業}

建等材料工業冲存在的主要情况, 同样也是品种狹窄与賀量不高。它在技術發展上 的重點措施应該集中力量來解决品种与貿量。问時对挆用新技術和改羓粉鷹等間是也应 有進一步的措施。

在据大品种方面: 今後应通过科学研究來試製各种高标号、新标号的话級水泥。在

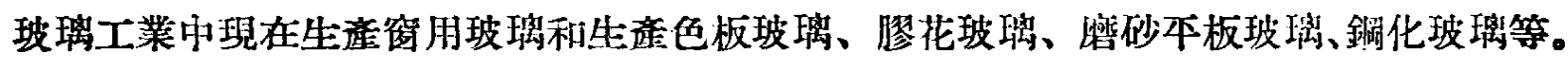

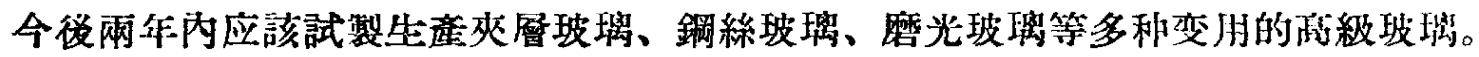

在改進逢品啠量上: 在水泥工業中应該注意第一，加强原料管理工作，降低尘料成 分的波動幅度；第二，大力加强熱工管理工作，增加必要的儀表，实行燃燒控制，耤以 達到一方面能的允分利用熱能，另方面生料進料速度能与熱量负荷相適应。在玻璃工業 中论同样要加强原料管理工作和加强配料控制工作。在玻琌的熱工控制方面应坦加儀表

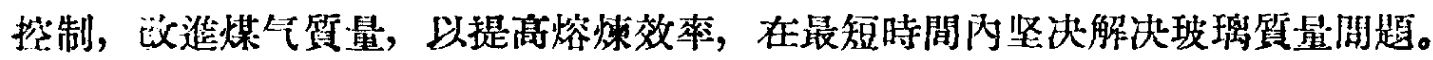

晕筑析料工業中应注意推席以下各項先進經驗。

水泥企業：第一，推廣廣州水泥做大籍安全运轉 267 天的先進経驗及苏联胴体水冷

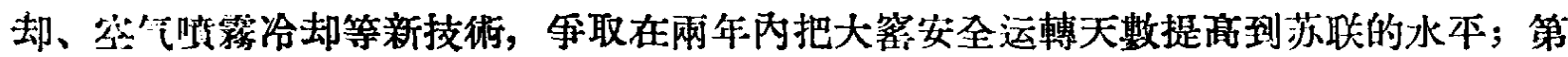

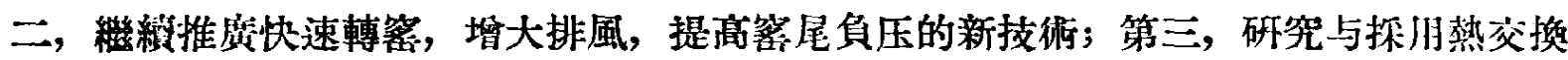

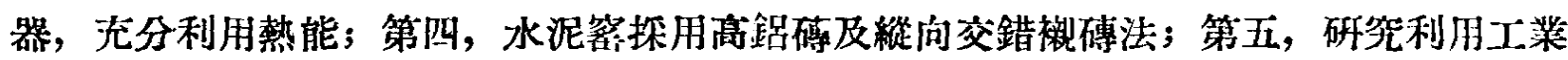

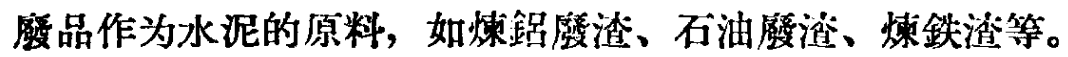

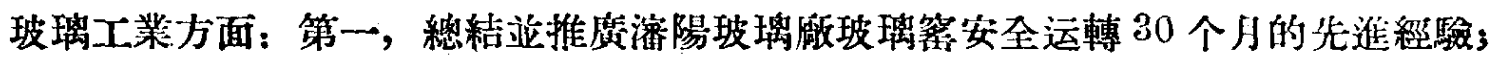

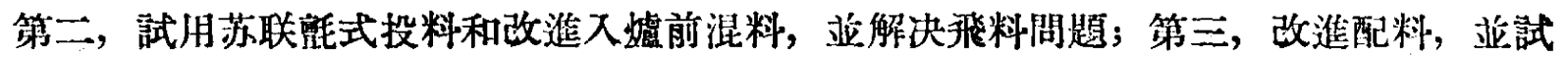
驗以证俏代替純碱。

此外，对國际、出現的新技獄.也廣泛应進行資料的搜集与試驗研究工作。

在上面，我們瑅出了各个垶業系統在今後兩作的技術發展中的若干重點問題。它地
- 38 .
科学通砕
1956 年 


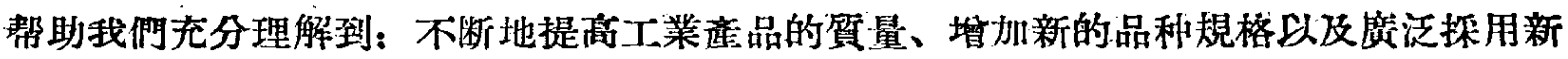
技術成就是流会主义工業生產中的一項栍本要求。但要有效地解决这一複雜的任务, 就 需要在谷方面做許多工作，其中一項十分重要的排有根本性質的工作就是为强工策部阴 本身的科学技術研究工作的問題。幾年爽我們在建犃科学試驗工作上地筜探取了若干措 施。但現在的间题是党和國家问我們的生產企業和科学工作者提出了更新的和更多的要

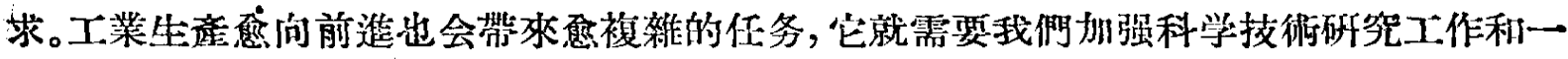
系列的組織工作。現在科学試驗研究工作是生產技術活動的整个䤲条中的一个重要的但 却是薄弱的环節。不难理解，複雜的品种和買量任务、合理利朋資源和推度新技術的任 务, 如果没有正確的技術領導和得力的科学技術研究工作，将是不可能实現的。科学研 究工作是保証工業生產技術發展的重要武器, 如果生產領導人員不關心它和加强它, 那 末任何複雜的技術难題是不可能得到順利解决的。因此，把科学試驗研究工作擺到雷工 業部系統各級領尊的請事H程上來，坚决地探取進一步加强它的指施，就成为十分必要 也十分迫切的閂題了。

到現在为止, 我們的科学試羷研究机棈有兩个主要部分: 一个是各專業的綜合研究 所，另一个是企業中心試驗室或試驗窒。幾年來我們为研究机關配备了一定數量的技術

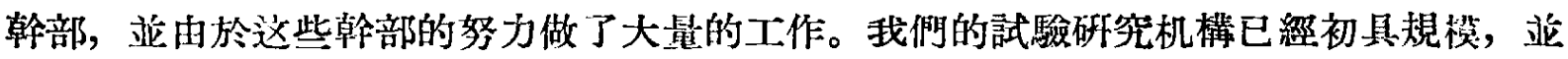

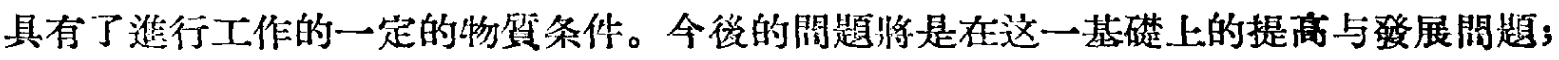
将是繼絓加强色和調整它的開題。

在我們科学試驗呼究工作的發展过程中，有如下一个重要事实需要指出的：这就是 各个亭業所開始是为了基本建設提供設訃教据这一方面的工作而建让和發展起來的; 各 中心試驗室是为了执行部碩标準，为了殿行訂貨任务，在检驗分析成品、牛成品、原材 料工作中建立起來的。这一事实是符合客覌事物發展要求的，是邀应重工柴从工栄惔復 階段起问工業建設階段的特點的。因而，这一事实也必然反映到我們的研究所和試驗宣

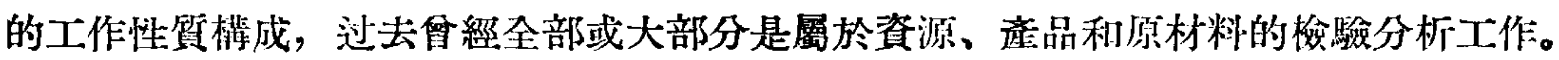
近年以來不少所和某些試驗室已開始从檢驗階段逐步地轉泃研究工作，当然，这利轉变 在各所等空还是不相同的。为了適应这种轉变，我們必須援大研究工作的比雪泣不断提 高呼究工作的罂量。

加强科学技術砰究工作的主姴途徑, 我們初步提出四點意見。

第一、需要淮一步規定研究所及中心試驗堂的工作任务与職珼分工，並且把它体現 到研究詿劃中去。

各个研究所及其分所的主要工作任务是为提高与發展本重桇的工業水本而服务的。

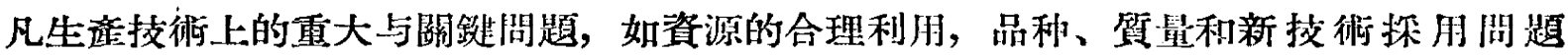
等, 研究所都应作为自己工作的基本任务加以研究与逐步解决; 另一方面研究所还应逐 步培养自己成为本亭桨的科学技術研究的核心, 不僅能䏯任比較高級的研究任务, 证且 能帮助中心試驗宝培莎幹部，在業务与技術上給以指導。研究所負有統一試驗方法、統 一研究制度、协问製訂与番查主要產品标準及基本操作規程的任务; 負有供給某些特殊 品样品、交流國际技術成就与先進經驗的任务; 特別是有統一考虏研究訐劃並組䋐协 作的任务。

1 月号 


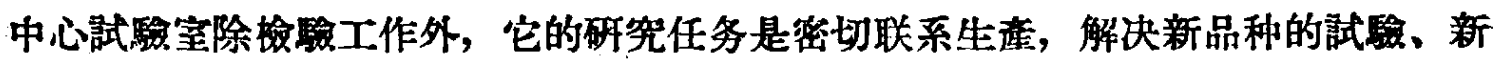

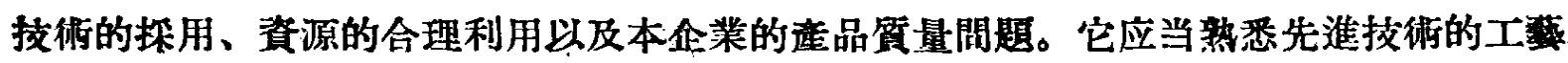
过程，应当有經常的技狱分析，应当善於协阅車間總結本企業的先進經驗，应当研究苏 联專家建議以及職工的重要合理化建議。中心試駼室应成为企業的强有力的技術机構, 成为倣長、總工程師的最重要的技術助手。

第二, 需要進行研究計劃的長远規劃; 同時也需要对今後研究机關組織發展上加以 規劃。

我們要求各个研究所今後根据技術發展計劃, 根据生应技術發展中的新閥題, 着手 考慮比较長远的研究部劃。企業中心呀驗室招应根据本企業的技術發展計劃在僘長、總 工程版領導下做出年度試驗研究計劃。

对於研究所的組織發展規劃開題: 要求对研究机構当前階段的組䋐發展詰劃, 和較 長远的組織發展計劃進行研究（包括中間試驗工激的設置与分工.，設备与基建，翰部与 技術力量的發展和培养等)，經过討論後，定:取有步驟地实現它，侧加鋼鉄方面須迅速

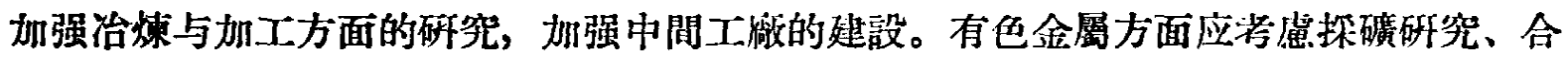

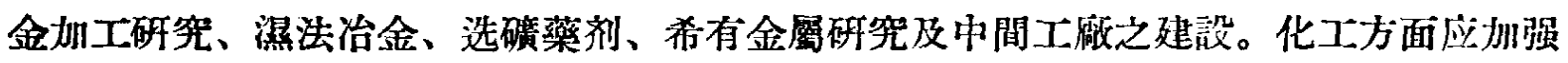

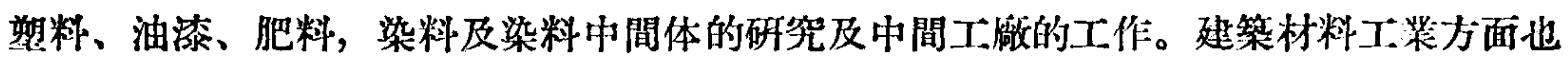
应考慮水泥、玻璃等工藝的措大研究工作。

第三, 就当前情况來說, 適当地加强研究所和中心試驗穼的技術力量的配备, 是州 强科学技術試驗研究工作的决定性的措施, 沒有技術等幹, 是不可能实現以上各項任务

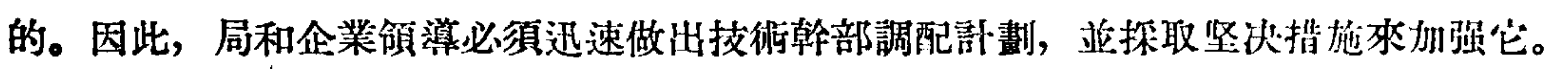

第四, 加强研究工作的主要方法和措施还有賴於各局、各企業領蕉把研究所、試驗 室的工作㨢到經常議程上來。当然，加强科学研究工作也特別有賴於研究机關加强其自 身領導。科学研究工作的水平决定着工業的數量和買量的塯長速度。为了順利地完成重 工業生迹進一步增長的任务, 全面地加强科学技術研究工作的实际活動, 皘極地探取措 施加强研究工作的規劃和領導, 就成为一个十分重要的間題, 重工業部希望通过这次会 議把各个亭業和各个企業的科学研究工作進一步加强起來。 